\title{
CHARAKTERISTICKÉ ASPEKTY ANAXIMENOVY KOSMOLOGIE
}

\section{Radim Kočandrle}

Anaximenés z Milétu je zpravidla hodnocen jako myslitel, který v kosmologii ustoupil od smělých vizí svého předchůdce Anaximandra směrem $\mathrm{k}$ tradičním výkladům. Měl opustit pojetí Země volně umístěné v prostoru a nebeská tělesa nechat obíhat pouze nad Zemí. Anaximenova kosmologie však obsahuje řadu nejasných míst, o nichž se lze domnívat, že dosud nebyla uspokojivě vysvětlena a mohla by Milét'anův obraz změnit.

Ačkoli jsme o Anaximenově myšlení pojednali již dříve, $v$ této studii se budeme věnovat pouze hlavním aspektům jeho kosmologie. ${ }^{1}$ Zejména se zaměříme na to, jak podle Anaximena vznikla nebeská tělesa, jakou podle něho mají povahu a jak vysvětluje dráhy jejich oběhů. Uvidíme, že dostatečné porozumění oběhům nebeských těles umožní vymezit nejen povahu těchto těles, ale i hlavní rysy Anaximenova universa. Zároveň pomůže identifikovat textové dodatky pocházející z pozdních koncepcí. Poukážeme přitom na to, že Anaximenova kosmologie představovala hlavní proud archaického iónského vysvětlení kosmologických dějů.

\section{Vznik nebeských těles}

Anaximenovo učení o vzniku nebeských těles máme v zásadě doloženo pouze ve zprávách pseudo-Plútarcha a Hippolyta. Pseudo-Plútarchos je zasazuje do obecného motivu změny prostřednictvím zhušt'ování a zřed’ování vzduchu. Navazuje tak na peripatetickou tradici, podle níž Ana-

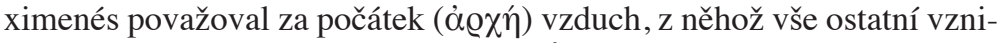
kalo na základě jeho zhuštování a zřed’ování. Ačkoli se zde nebudeme daným problémem zabývat, řekněme, že je to právě kosmogonický proces, který významným způsobem narušuje schéma transformací vzduchu v různé složky světa, považované běžně za nejdůležitější Anaximenův

1 Viz zejména R. Kočandrle, Anaximenés z Mílétu, Červený Kostelec 2014. 
přínos. Přestože texty popisují pouze vznik nebeských těles, a přestože tedy celý postupný proces proměn vzduchu mohl být ponechán stranou, lze se domnívat, že se v jeho př́ípadě jedná až o pozdní systematizaci. ${ }^{2}$

$\mathrm{V}$ pseudo-Plútarchově zprávě se jako u jediného z autorů objevuje stručný nástin vzniku Země, od něhož se následně odvíjí i vznik ostatních nebeských těles:

„Anaximenés prý řekl, že počátkem veškerenstva je vzduch, a ten že je bezmezný co do velikosti, je však určený svými kvalitami. Všechno se rodí podle jeho zhušt'ování a zase zřed’ování. Pohyb existuje od věčnosti. Říká, že kontrakcí vzduchu vznikla nejprve velmi plochá Země. Proto také dává smysl, že je nadnášena vzduchem. Slunce, Měsíc a ostatní hvězdy (őơ@ $\alpha$ ) mají počátek svého vzniku ze Země. Opravdu tedy tvrdí, že Slunce je Zemí a že nabývá dostatečné teploty svým prudkým pohybem.“3

Zaměříme-li se výhradně na nebeská tělesa, vidíme, že ačkoli je jejich vznik vztažen k Zemi, není uvedeno v jakém konkrétním smyslu. Se vznikem nebeských těles souvisí i jejich povaha, kterou pseudo-Plútarchos v př́ípadě Slunce následně identifikuje s povahou Země. Pokud předtím uvádí i Měsíc a „ostatní hvězdy“, lze se domnívat, že všechna tělesa mají tutéž - zemitou - povahu. Ta je navíc v případě Slunce akcentována vysvětlením jeho tepla prudkým pohybem.

Konkrétní popis vzniku nebeských těles přibližuje Hippolytos. Jeho svědectví se však od pseudo-Plútarchova významně liší, ačkoli podobně vynechává nejranější kosmogonickou fázi:

2 Srv. N. Ch. Dührsen, Anaximenes, in: H. Flashar - D. Bremer- G. Rechenauer (vyd.), Frühgriechische Philosophie. Die Philosophie der Antike, I, Basel 2013, str. 327; D. W. Graham, Explaining the Cosmos. The Ionian Tradition of Scientific Philosophy, Princeton 2006, str. 74-75; P. Hobza, Aristotelés a Theofrastos jako tvưrci mílétské filosofie, in: Filosofický časopis, 6, 2004, str. 920-921; U. Hölscher, Anaximander und die Anfänge der Philosophie, in: Hermes, 81, 1953, str. 273-274, 414; J. Klowski, Ist der Aer des Anaximenes als eine Substanz konzipiert?, in: Hermes, 100, 1972, str. 133-140; J. Moran, Ps.-Plutarch's Account of the Heavenly Bodies in Anaximenes, in: Mnemosyne, 26, 1973, str. 9-14; The Priority of Earth in the Cosmogony of Anaximenes, in: Apeiron, 9, 1975, str. 17-19; G. Wöhrle, Anaximenes aus Milet. Die Fragmente zu seiner Lehre, Stuttgart 1993, str. 18-23, 57-58.

3 DK 13 A 6. Není-li uvedeno jinak, překlady antických autorů pořídil na základě starších překladů V. Hladký a kol., viz R. Kočandrle, Anaximenés z Mílétu, str. 18-47. 
„Země je plochá a vznáší se na vzduchu; podobně i Slunce a Měsíc

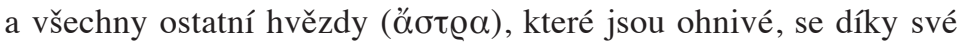

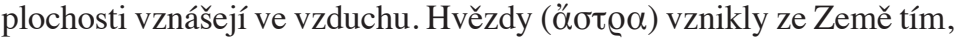
že z ní vystupuje vláha, jejímž zřed’ováním vzniká oheň, a z ohně,

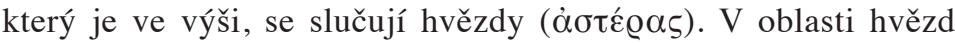

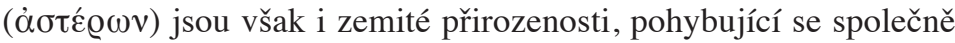
s nimi v kruhu. “4

Zatímco pseudo-Plútarchos akcentoval zemitou povahu nebeských těles, Hippolytos jednoznačně hovoří o tom, že byla ohnivá. Ohnivost nebeských těles souvisí s jejich vznikem, nebot' je dán vypařováním vláhy ze Země, jejím následným zředěním a zapálením. Ohnivost je navíc zdůrazněna odlišením ,zemitých přirozeností“. Ačkoli je tak Země opět explicitně zmíněna a stojí na počátku vzniku nebeských těles, hraje pouze roli místa, kde začíná vlastní vypařování. Nebeská tělesa by tak měla mít zemitou povahu pouze $\mathrm{v}$ přeneseném smyslu. Ve skutečnosti jsou jen produkty vypařování zemské vlhkosti.

Vyvstává však otázka, zda Hippolytos hovoří pouze o hvězdách, nebo zda jeho popis zahrnuje i Slunce a Měsíc. Zatímco totiž pseudo-Plútarchos vše demonstruje na př́kladu Slunce, Hippolytos se zmiňu-

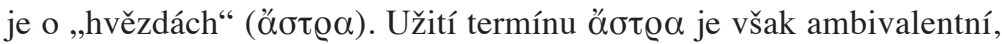
nebot' může vyjadřovat jak hvězdy - stálice, tak nebeská tělesa obecně. ${ }^{5}$ Pokud Hippolytos v předchozí větě uvádí ,Slunce, Měsíc a všechny ostatní hvězdy“, byt' v odlišném kontextu - jde o jejich vznášení ve vzduchu -, lze se domnívat, že termín ő $\sigma \tau \varrho \alpha$ zastupuje i Slunce a Měsíc. Zamýšlený rozdíl je spíše akcentován až v samém závěru „zemitými přirozenostmi“.

Ohnivou povahu Slunce a Měsíce navíc opakovaně dosvědčuje Áetios: „O podstatě Slunce: Anaximenés a Parmenidés [ř́íkají, že Slunce je] ohnivé.“6 „O podstatě Měsíce: Podle Anaximena, Parmenida a Hérakleita je Měsíc ohnivý. “7 Podobně přisuzuje ohnivou povahu Měsíci i Theodorétos: „A o Měsíci pak povídají: Thalés říká, že je zemitý,

\section{$4 \quad D K 13$ A 7.}

5 Srv. G. S. Kirk - J. E. Raven - M. Schofield, Předsókratovští filosofové. Kritické dějiny s vybranými texty, přel. F. Karfík - P. Kolev - T. Vítek, Praha 2004, str. 200.

$6 \quad D K 13$ A 15.

$7 \quad D K 13$ A 16. 
Anaximenés, Parmenidés a Hérakleitos, že sestává pouze z ohně.“8 Ter-

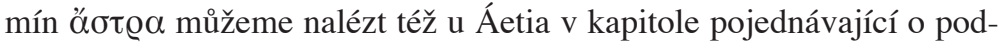
statě rozličných nebeských těles. Již vzhledem k užití termínů ả $\lambda \lambda \alpha v \eta ́ s$ a $\alpha \dot{\tau} \lambda \alpha v \omega ̂ v$ se lze domnívat, že zde obecně zastupuje nejen nebeská tělesa, ale především Slunce a Měsíc:

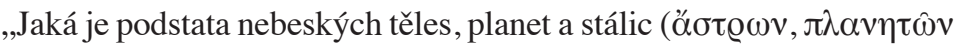
xoì $\alpha \pi \lambda \alpha v \hat{\omega} v)$ : Anaximenés říká, že přirozenost nebeských těles

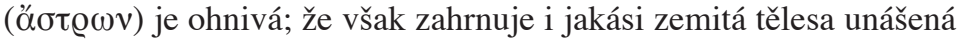
dokola spolu s nimi, která nejsou viditelná.“9

Pozoruhodné jsou zmínky o ,zemitých přirozenostech“ či ,zemitých tělesech“, které se v textech objevují. Vzhledem k tomu, že Áetios explicitně zmiňuje jejich neviditelnost, musí jít o ještě jiný druh těles, které jejich zemitý charakter od Slunce, Měsíce a hvězd odlišuje.

Pokud texty variují mezi ohnivou a zemitou povahou nebeských těles, musíme přihlédnout i $\mathrm{k}$ dalším charakteristikám a ptát se, zda nám nepomohou povaze těles lépe porozumět. Zásadní prvkem Anaximenovy kosmologie je přitom plochost nebeských těles.

Ačkoli pseudo-Plútarchos uvádí pouze vznik Země, dodává, že byla „velmi plochá“. Plochý tvar Země zároveň dává do souvislosti s tím, že je nadnášena vzduchem. Hippolytos celý model rozšiřuje i na ostatní nebeská tělesa, kdy plochost Země a nebeských těles uvádí jako důvod toho, že se vznášejí na vzduchu, přičemž jej podporuje Áetios: „O zemětřeseních: Anaximenés [o Zemi]: Díky plochosti je nadnášena vzduchem. “ ${ }^{10}$ Aristotelés plochý tvar Země explicitně zmiňuje jako příčinu její stability v universu:

„Anaximenés, Anaxagorás a Démokritos však tvrdí, že příčinou toho, že Země stojí, je její plochost. Nerazí si cestu vzduchem pod sebou, ale přikrývá jej jako poklice, což plochá tělesa zjevně dělají. Ta jsou totiž vůči větru nehybná díky protitlaku. Tvrdí, že takto to činí i Země svou plochostí vůči vzduchu pod ní. Vzduch nemá dostatečné místo, aby se pohnul, zůstává dole a v klidu, jako voda v klepsydře.“11

8 G. Wöhrle (vyd.), Die Milesier: Anaximander und Anaximenes, Berlin - Boston $2012(=T P), 2$ As 113.

9 DK 13 A 14.

10 DK 13 A 20.

11 Aristotelés, De caelo II,13,294b13 = DK 13 A 20. 
Áetios navíc nabízí konkrétní představu o Zemi: „Podle Anaximena má Země podobu stolu. “12 Ačkoli o Měsíci nepřináší v tomto směru žádné zprávy, v př́ípadě Slunce také dokládá jeho plochý tvar, přičemž opět využívá konkrétního příměru: „O tvaru Slunce: Anaximenés a Alkmaión [ř́íkají], že Slunce je ploché jako list.“13

Přestože ke hvězdám přihlédneme až následně, lze konstatovat, že i když se texty ohledně povahy nebeských těles zcela neshodují, připisují jim plochý tvar. Abychom však mohli povahu nebeských těles dostatečně vymezit, musíme se zaměřit na jejich oběhy.

\section{Oběhy nebeských těles}

Oběhy nebeských těles představují jeden ze stěžejních problémů v Anaximenově kosmologii, nebot' dochované texty předpokládají situaci, která není na první pohled v souladu s běžným pozorováním. Všechny texty se totiž shodují v tom, že nebeská tělesa při svém oběhu nezasahovala pod Zemi, ale obíhala pouze kolem ní.

Když Hippolytos užívá konkrétní motiv plstěného klobouku, naznačuje tím původnost celého pojetí:

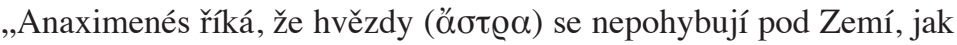
předpokládali jiní, nýbrž kolem Země, jako když se kolem naší hlavy točí plstěný klobouk. Slunce se neskrývá tím, že se pohybuje pod Zemí, nýbrž tím, že je kryto vyššími částmi Země - a také proto, že jeho vzdálenost od nás se zvětšuje. Hvězdy (ő $\sigma \tau \varrho \alpha)$ nehřejí proto, že jsou velice daleko.“14

Výklad oběhu nebeských těles zachovává i Diogenés Laertios: „Anaximenés, syn Eurystratův, Milét’an, byl posluchačem Anaximandrovým. Ř́kal, že počátkem je vzduch a [ten že] je bezmezný. Hvězdy se prý pohybují nikoli pod Zemí, nýbrž okolo Země." ${ }^{15}$ Áetios oběhu nebeských těles věnuje samostatnou kapitolu: „O oběhu a pohybu nebeských těles

\footnotetext{
$12 D K 13$ A 20.

$13 D K 13$ A $15=$ DK 13 B 2 a.

$14 D K 13$ A 7.

15 DK 13 A 1.
} 


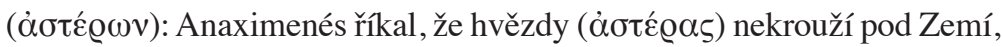
nýbrž okolo Země.“"16

Zatímco předchozí zprávy se týkaly převážně oběhu hvězd či obecně nebeských těles, Aristotelés ve spisu Meteorologika zmiňuje - obdobně jako Hippolytos - Slunce. Dané vysvětlení ale připisuje „,̌etným dávným meteorologům“:

„Dokladem toho, že severní část Země je vysoká, má být přesvědčení četných dávných meteorologů, že Slunce se nepohybuje pod Zemí, nýbrž kolem Země a její severní části; že mizí, a tak působí noc, protože směrem k severu je Země vysoká."17

Navzdory různým podobám se zprávy shodují v tom, že se hvězdy - nebeská tělesa - neměly pohybovat pod Zemí, ale okolo Země. Hippolytos v př́ípadě Slunce navíc upřesňuje, že k jeho stmívání dochází proto, že je „kryto vyššími částmi Země“. Bezesporu se jedná o vysvětlení každodenního příchodu noci, jak je zjevné z Aristotelova vyjádření.

Představené pojetí je obtížně pochopitelné hned v několika bodech, nebot' se rozchází jak s běžným pozorováním každodenního východu a západu Slunce, které jakoby „zalomilo“ svoji dráhu, tak se sklonem nebeského pólu. V zásadě reprezentuje situaci na pólu, s níž ovšem nemohl mít Anaximenés žádnou zkušenost. ${ }^{18}$

Obtíže, které předložené vysvětlení přináší, názorně přiblížil Richard D. McKirahan obrázkem, na němž je umístěna plochá Země na sloupu vzduchu, který ji podpírá. Země je zároveň vsunuta do nakloněné polokoule nebeské klenby. Nebeská klenba tak pokrývá jen část prostoru nad Zemí, zatímco na jihu zeje prázdný prostor bez hvězd. Plstěný klobouk z Hippolytova svědectví by v takovém případě byl nasazen šikmo na hlavě. ${ }^{19}$

Peter J. Bicknell naopak vyšel z koncepce nebe jako celé sféry, přičemž problém sklonu pólu vyřešil skloněním samotné Země, jak je doloženo u Leukippa a Démokrita. ${ }^{20}$ Nebeská tělesa pak neměla procházet

\footnotetext{
$16 \quad D K 13$ A 14.

17 Aristotelés, Meteor. II,1,354a28 = DK 13 A 14.

18 Srv. P. J. Bicknell, Anaximenes' Astronomy, in: Acta Classica, 12, 1969, str. 77; G. Wöhrle, Anaximenes aus Milet, str. 73-74.
}

19 Srv. R. D. McKirahan, Philosophy Before Socrates. An Introduction with Texts and Commentary, Indianapolis - Cambridge 1994, str. 57.

$20 \quad D K 67$ A 1; DK 67 A 27; $D K 68$ A 96. 
pod Zemí, ale jakoby za ní. Jak však správně upozornil Dirk L. Couprie, pro pozorovatele na Zemi by i tak stále procházela pod Zemí. ${ }^{21}$

D. L. Couprie v návaznosti na otázku sklonu pólu usoudil, že texty u Anaximena popisují nikoli aktuální stav oběhu nebeských těles, nýbrž situaci předtím, než došlo ke sklonu nebeského pólu. ${ }^{22}$ Třebaže je dané řešení jednoduché a elegantní, pokládáme za signifikantní, že - jak poukážeme dále - problém sklonu pólu je doložen až v kosmologii následující po Parmenidovi.

Daniel W. Graham představil obraz Anaximenova universa, v němž nebeská tělesa obíhají pouze nad plochou Zemí, přičemž hvězdy jsou pevně zafixovány do nebeské klenby. Slunce přitom při svém pohybu zachází za vysoké pohoří na severu. Jakkoli Grahamův výklad sleduje obsah textů, nepřináší bližší objasnění celé situace. Uvidíme, že již v př́ípadě každodenního východu a západu Slunce by totiž znázorněné pohoří nemělo sehrávat roli. ${ }^{23}$

Ačkoli dochované texty popisují oběhy nebeských těles, nijak je konkrétně nevysvětlují. Můžeme se samozřejmě domnívat, že potíže, které si dnes uvědomujeme, nebyly v archaické době vyřčeny. Dmitri Panchenko ${ }^{24}$ však upozornil na čínskou kosmologickou koncepci gai tian (,nebeská pokrývka“), která by nám mohla pomoci celému kosmickému dění, jak je u Anaximena popsáno, porozumět.

\section{Gai tian}

Kosmologická koncepce gai tian je popsána v různých pramenech. Hlavním pramenem je spis Zhou bi suan jing pocházející z doby dynastie Chan (206 př. Kr. - 220 po Kr.). Jiným pramenem je spis Lun-Hêng, jehož autorem je Wang Chong, který žil v 1. století po Kr. Zmíněný text

21 Srv. P. J. Bicknell, Anaximenes' Astronomy, str. 78; D. L. Couprie, The Paths of the Celestial Bodies According to Anaximenes, in: Hyperboreus, 21, 2015, str. 15; G. Wöhrle, Anaximenes aus Milet, str. 74-75.

22 Srv. D. L. Couprie, The Paths of the Celestial Bodies According to Anaximenes, str. 5-32.

23 Srv. D. W. Graham, Science Before Socrates. Parmenides, Anaxagoras, and the New Astronomy, New York 2013, str. 65.

24 Srv. D. Panchenko, Anaximenean Astronomy in the Light of Chinese Parallels, in: Tsinghua Studies in Western Philosophy, 1, 2015, str. 412-426; The City of the Branchidae and the Question of Greek Contribution to the Intellectual History of India and China, in: Hyperboreus, 8, 2002, str. 251. 
tak pochází z pozdější doby, a navíc nikde nepoužívá termín gai tian, ani zhou bi. Ačkoli Ch. Cullen označuje jeho hodnotu za marginální, budeme $\mathrm{k}$ němu přihlížet zejména proto, že obsahuje různé názorné př́klady. ${ }^{25}$

Východiskem celé koncepce je pojetí Země a nebe jako dvou oddělených paralelně ležících rovin, které se nikde nestýkají. ${ }^{26}$ Země je pojata jako plochá ve tvaru čtverce, zatímco ploché nebe má tvar kruhu. ${ }^{27}$ Země je nehybná, nebe se naopak pohybuje konstantní rychlostí. Slovo gai přitom vyjadřuje stř̌išku podobnou deštníku (či slunečníku) umístěnému nad vozem. ${ }^{28}$

Pro naše účely není třeba koncepci gai tian detailněji rozebírat, zaměřme se pouze na předpoklad, že hvězdy jsou umístěné na plochém nebi, které se otáčí nad plochou Zemí. Slunce a Měsíc mají vlastní pohyb od západu k východu, ale vzhledem k tomu, že jsou unášeny nebem, pohybují se od východu k západu. Pohyb Slunce a Měsíce je přirovnán k pohybu mravenců na otáčejícím se mlýnském kameni. S motivem mlýnského kamene se přitom setkáváme i u Anaximena. ${ }^{29}$

Nebeská tělesa obíhají kolem nebeského pólu po kruhových drahách paralelních k povrchu ploché Země. Při svém oběhu tak nezasahují pod její povrch. Když při východu a západu vzniká dojem, že Slunce vychází nad Zem a zachází pod Zemi, jde pouze o důsledek působení vzdálenosti. Východ a západ Slunce jsou pouhou optickou iluzí způsobenou změnou jeho vzdálenosti od pozorovatele. Když se k nám Slunce přibližuje, zdá se, že vychází zpoza horizontu, zatímco když se od nás vzdaluje, zdá se, že za horizont zapadá. Slunce ale po svém domnělém západu ve skutečnosti pokračuje po kruhové dráze dále nad Zemí, nalézající se stále ve stejné výši, aby se následně znovu objevilo na východě..$^{30}$

Role perspektivy má v celém systému naprosto nezastupitelnou úlohu. Slunce navíc svítí pouze na omezenou vzdálenost. Při svém oběhu postupně osvětluje vždy jen část Země pod sebou. Samotný dosah světla

25 Srv. Ch. Cullen, Astronomy and Mathematics in Ancient China: The Zhou bi suan jing, Cambridge 1996, str. 1, 60-61, pozn. 63; D. Panchenko, The City of the Branchidae and the Question of Greek Contribution to the Intellectual History of India and China, str. 251.

26 A. Forke, Lun-Hêng. Philosophical Essays of Wang Ch'ung, Leipzig - London - Shanghai 1907, str. 261-262 (dále jen: Wang Chong, Lun-Hêng).

27 Zhou bi suan jing, A6, vyd. Ch. Cullen, in: Astronomy and mathematics in ancient China, str. 174.

28 Ch. Cullen, Astronomy and Mathematics in Ancient China, str. 50.

29 Wang Chong, Lun-Hêng, str. 265-266.

30 Tamt., str. 261-262. 
Slunce tak zásadně souvisí s rozsahem jeho viditelnosti. I sám pozorovatel dohlédne jen na omezenou vzdálenost. ${ }^{31}$

Ve chvíli, kdy z našeho pohledu Slunce zapadá na západě, pro obyvatele žijící v této oblasti naopak kulminuje. Slunce tak při svém pohybu nevychází a nezapadá pro všechny oblasti na Zemi ve stejný čas, nýbrž při svém pohybu postupně osvětluje jednotlivé části Země - když se nalézá v oblasti severně od pólu, je v severní oblasti poledne, zatímco v jižní půlnoc..$^{32}$ Noc nastává, jakmile Slunce překročí vzdálenost, na kterou dosahuje jeho světlo. ${ }^{33}$

Důsledkem vzdálenosti je i zdánlivá výše nebeských těles. Nebeská tělesa, která jsou blíže, se zdají být vysoko, zatímco ta, která jsou vzdálená, se naopak zdají být nízko. Ve skutečnosti však obíhají stále ve stejné výši nad povrchem Země. V poledne je Slunce nejblíže pozorovateli a v tu dobu je také nejtepleji. Při východu a západu je naopak dále a je chladněji. Během jeho kulminace se navíc jeví menší než při východu a západu, nebot' za dne není oheň tak nápadný, jako za soumraku. ${ }^{34}$

Ačkoli pohyb Slunce a Měsíce souvisí s pohybem nebe, které se otáčí výrazně větší rychlostîin a směr oběhu obou nebeských těles obrací, přesto se pohybují na nebi nezávisle. Průměr jejich oběhu kolem pólu se navíc v průběhu času mění. Rozdílné délky dne a noci v létě a zimě i samotný průchod jednotlivých ročních dob je dán zvětšováním a následným zmenšováním průměru kruhové dráhy Slunce.$^{36}$ Kruhová dráha oběhu Slunce dosahuje svého minima v době letního slunovratu, zatímco v době zimního slunovratu naopak dosahuje svého maxima. ${ }^{37}$

Pokud je celé dění na nebi dáno pouze optickou iluzí, klíčové je vlastní umístění pozorovatele. Obývaná země - Čína - je přitom situována na jih a zabírá tak pouze malou část rozlohy Země. ${ }^{38}$ Jsou-li nebe a Země

31 Srv. D. Panchenko, Anaximenean Astronomy in the Light of Chinese Parallels, str. 414.

32 Zhou bi suan jing, E4 (Cullen, str. 189).

33 Srv. D. Panchenko, Anaximenean Astronomy in the Light of Chinese Parallels, str. 417.

34 Wang Chong, Lun-Hêng, str. 263-265.

35 Tamt., str. 266.

36 Zhou bi suan jing, B16, B17, B18, B19, B21, B34 (Cullen, str. 179-181).

37 Srv. D. L. Couprie, An Ancient Chinese Model of a Flat Earth and a Flat Heaven, str. 437-440; D. Panchenko, Anaximenean Astronomy in the Light of Chinese Parallels, str. 417.

38 Wang Chong, Lun-Hêng, str. 255. 
dvě paralelně ležící plochy, které jsou od sebe shodně vzdáleny, přičemž centrum Země se nalézá přímo pod pólem, kolem něhož se otáčí nebe, pozorovaný sklon nebeské osy je pouze zdánlivý, nebot' je důsledkem jižně umístěného místa pozorovatele. Problém naklonění pólu - tedy potř̌eba zdůvodnění, proč pól nesplývá se zenitem a nebeská osa tak není kolmá k rovině Země - v čínské koncepci vůbec nenastává. ${ }^{39}$

Akceptujeme-li východiska čínské koncepce gai tian rámcově rovněž u Anaximena, výše představená interpretace D. L. Couprieho se ukazuje jako nadbytečná. Problém sklonu pólu v archaické iónské kosmologii nemusel vůbec existovat. Nemusí být proto překvapením, že je doložen právě až v koncepcích z doby po Parmenidovi, které již vycházely ze zcela jiných pojetí, jak prostoru, tak nebeských těles.

Ačkoli pokládáme koncepci gai tian pouze za analogický způsob vysvětlení dění na nebi, domníváme se, že její předpoklady mohou osvětlit oběhy nebeských těles u Anaximena.

\section{Optická iluze a prostor pod Zemí}

Pokud se vrátíme k Anaximenovi, shledáme, že ačkoli texty vesměs opakují informaci o oběhu těles kolem Země, Hippolytos zmiňuje dvě skutečnosti týkající se Slunce, které vstupují do hry. Slunce se nemá skrývat tím, že „se pohybuje pod Zemí, nýbrž tím, že je kryto vyššími částmi Země - a také proto, že jeho vzdálenost od nás se zvětšuje. “" ${ }^{“ 40}$ Ve druhém z momentů, který explicitně zmiňuje vzdalování Slunce od naší pozice, můžeme spatřit úzkou paralelu s vysvětlením podaným v koncepci gai tian. Východ a západ Slunce jsou tak pouze optickou iluzí. ${ }^{41}$

Badatelé ovšem obvykle akcentují první ze zmíněných důvodů. Viděli jsme, že podobně Aristotelés přináší zdůvodnění vysoké severní části Země, nebot' díky ní Slunce mizí a nastává noc. ${ }^{42}$ Již vzhledem ke kolonizaci Černého moře se lze domnívat, že Řekové byli obeznámeni s tím, že směrem k severu se Země postupně zvedá. K tomu je mohl ostatně vést i fakt, že zdejší velké řeky tečou jižním směrem. Právě to je

39 Srv. D. Panchenko, Anaximenean Astronomy in the Light of Chinese Parallels, str. 415-416.

40 DK 13 A 7.

41 Srv. D. Panchenko, Anaximenean Astronomy in the Light of Chinese Parallels, str. 413-414.

42 Aristotelés, Meteor. II,1,354a28 = DK 13 A 14. 
jádrem Aristotelova referátu, v němž vysoká severní část Země nejspíše reprezentuje horská pásma na severu (mytické pohoří Rhipai), odkud tečou velké řeky. Mohl by se zde přitom uplatňovat prastarý motiv hory umístěné ve stř̌edu světa, přítomný v různých kulturách. Residuum může představovat dochované vyobrazení světa s indickými prvky doložené u Kosmy Indikopleusta z 6. století po $\mathrm{Kr}^{43}$ I zde Slunce vychází a zapadá za velkou horou (Méru), která se tyčí na severu nad plochou Zemí. Jak ale upozorňuje D. Panchenko, pokud Slunce mezi podzimní a jarní rovnodenností vychází a zapadá jižně od pozorovatele nalézajícího se kdekoli na řeckém území, celé Aristotelem uváděné zdůvodnění postrádá smysl. Přesto se lze domnívat, že se zde scházejí oba motivy - vysoká severní část Země a vzdalování Slunce. Postupné skrytí Slunce za horizontem mohlo být s představou severní hory prirozeně spojeno, aniž by ovšem spolu oba momenty ve skutečnosti souvisely. Navzdory obvyklým interpretacím je však v celé koncepci určující vzdalování Slunce spojené s optickou iluzí jeho západu. ${ }^{44}$

Nebeská tělesa tak podle Anaximena obíhala pouze nad plochou Zemí, přičemž jejich východ a západ byly pouhou optickou iluzí způsobenou vzdalováním od pozorovatele. Ten se přitom nalézal jižně od pólu, středu všech oběhů, jehož sklon byl tedy podobně iluzorní. Světlo Slunce dosahovalo jen na určitou vzdálenost, za níž nadcházela tma. Dráha Slunce se navíc během roku zvětšovala a následně zmenšovala, přičemž tak určovala délku dne a noci i průchod ročních dob.

Pokud si však Slunce během svého celoročního oběhu udržuje stále stejnou velikost, kterou dnes udáváme v úhlové mîre přes půl úhlového stupně, naskýtá se v této souvislosti otázka, jak mohl daný fakt Anaximenés vysvětlit. Mohl se domnívat, že se dráha oběhu Slunce v průběhu roku nejen postupně zvětšuje a následně zmenšuje, ale že Slunce zároveň v jedné polovině roku klesá, zatímco ve druhé stoupá. V době letního slunovratu se tak nalézá na nebi nejvýše - přičemž obíhá po dráze s nejmenším poloměrem -, zatímco v době zimního slunovratu se naopak nalézá nejníže a zároveň opisuje nejdelší dráhu. Jeho dráha by přitom měla tvar seříznutého kužele. Velikost Slunce by tak byla pro pozorovatele v zásadě konstantní. Slunce by se v průběhu roku střídavě pohybovalo

43 K. Indikopleustés, Topographia christiana, IV (J. W. McCrindle, The Christian Topography of Cosmas, an Egyptian Monk, London 1897, apendix, obr. 7, 8).

44 Srv. U. Hölscher, Anaximander und die Anfänge der Philosophie, str. 413; G. S. Kirk - J. E. Raven - M. Schofield, Předsókratovští filosofové, str. 202; D. Panchenko, Anaximenean Astronomy in the Light of Chinese Parallels, str. 414, 419-420; M. L. West, Early Greek Philosophy and the Orient, Oxford 1971, str. 103, 106-107. 
mezi plochou Země a nebem - a jak uvidíme dále - stlačovalo by přitom svým tělesem vzduch, který by jej střídavě vynášel a zase spouštěl. Ačkoli D. Panchenko uvádí danou možnost oběhu Slunce, nespojuje ji S relativní velikostí slunečního terče..$^{45}$

Uplatněním klíčových prvků čínského pojetí navíc získá smysl i jiná iónská koncepce kosmologie, která obvykle přináší nemálo obtíží:

„Xenofanés [ř́kal, že] je mnoho Sluncí a Měsíců podle oblastí, částí a pásů Země, a že v určitém čase padá disk na některou námi neobydlenou část Země, a když takto vstupuje do pustiny, ukazuje zatmění. Také říká, že Slunce kráčí vpřed do nekonečna; kvůli vzdá-

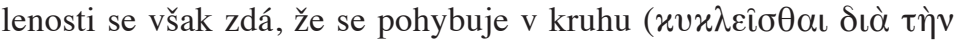

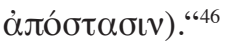

Množství Sluncí a Měsíců „podle oblastí, částí a pásů Země“ můžeme u Xenofana z Kolofónu rozumět ve smyslu postupného ,průchodu“ zmíněných nebeských těles nad těmito neobydlenými oblastmi, právě tak, jak jsme viděli v koncepci gai tian. Odtud lze vyložit i závěrečnou větu stavící zjevně proti sobě pohyb Slunce po přímé nebo kruhové dráze. Na první pohled by text mohl akcentovat dráhu Slunce v rozporu s pojetím, s nímž jsme se setkali v koncepci gai tian, kde Slunce opisuje kruhovou dráhu nad Zemí. Můžeme se však zaměřit pouze na dráhu Slunce, kterou vidíme během dne, kdy Slunce vychází na východě, kulminuje na jihu a zapadá na západě. Slunce tak postupně vidíme v různé výši nad obzorem, přičemž opisuje půlkruh. Text se přitom doslova zmiňuje o optické iluzi, kterou zdůvodňuje vzdáleností Slunce od nás. Pozorovaný pohyb v kruhu bychom tak mohli vyložit jako zdánlivý v závislosti na tom, že čím se k nám Slunce nalézá blíže, tím se jeví výše. Xenofanés by tedy ve skutečnosti upozorňoval, že se Slunce při svém oběhu nalézá stále ve stejné výši. Mohlo by se přitom jednat o kritickou reakci na Anaximandra, ${ }^{47}$ podle něhož měla nebeská tělesa naopak př́imo sestávat z šikmo ležících kruhů. ${ }^{48}$

45 Srv. D. Panchenko, Anaximenean Astronomy in the Light of Chinese Parallels, str. 422-423.

$46 D K 21$ A 41a.

47 DK 12 A 22.

48 Srv. D. Panchenko, Anaximenean Astronomy in the Light of Chinese Parallels, str. 414-415; M. L. West, Early Greek Philosophy and the Orient, str. 103. 
Ačkoli je zařazení Xenofanova myšlení obtížné - Xenofanés bývá kladen do italské větve filosofie -, lze se domnívat, že jeho kosmologie původně vychází právě z iónské tradice. Akcentuje totiž obdobná témata a jím předložená vysvětlení jsou iónským velmi blízká. ${ }^{49}$

Nalézáme-li tak explicitně u Anaximena a ve zřejmých náznacích u Xenofana popis oběhu nebeských těles výhradně nad Zemí, který ani zprávy u Hérakleita nerozporují, lze jej pokládat za jeden z typických znaků iónského archaického vnímání světa. A jak uvidíme dále, zásadně souvisel s povahou nebeských těles. Odtud získává smysl i následující Áetiova zmínka: „Jedni se domnívají, že [svět] se otáčí jako mlýnský kámen, jiní zase, že jako kolo. “50 Je přitom možné soudit, že vysvětlení oběhů nebeských těles pouze nad Zemí původně vycházelo z epické tradice. Jednalo se tak o další zhodnocení a rozvedení pojetí světa, v němž se nebe rozkládalo nad plochou Zemí s hlubinou Tartaru, ${ }^{51}$ přičemž právě oddělení a nedosažitelnost hloubek Země, v nichž má své kořeny, bylo jedním z charakteristických prvků. ${ }^{52}$

Pozoruhodná je v tomto smyslu cesta Slunce, kterou vykonává v noci po svém západu. Homér se ale doslova zmiňuje pouze o zacházení boha Hélia ,pod zem“53 a o jeho opětovném vycházení. Jinde hovoří o tom, že se Slunce zvedá z hlubokých Ókeanových proudů, nebo naopak o sestoupení sluneční záře do Ókeanu. ${ }^{54}$ Ókeanos je přitom popisován jako „tekoucí nazpět" ${ }^{55}$ jako by obklopoval kruhovou Zemi. Ačkoli sám Homér o noční cestě Slunce nic konkrétního neříká, Mimnermos píše o cestě, kdy Hélios v kraji Hesperidek uléhá na okřrídlené zlaté lože a spící koná cestu po vodní hladině do země Aithiopů, aby opět vstoupil na svůj vůz. ${ }^{56}$ Stésichoros ${ }^{57}$ se obdobně vyjadřuje o zlaté číši. Výraz zacházení Slunce „pod zem“ bychom proto mohli vnímat pouze v oslabeném smyslu jeho

49 Srv. D. W. Graham, The Texts of Early Greek Philosophy, Cambridge 2010, str. 96-97.

50 DK 13 A 12.

51 Např. Hésiodos, Theog. 726; 744-54; Homér, Il. V,504; VIII,13; XVII,425; Od. III,2; XV,329; XVII,565.

52 Srv. D. W. Graham, Science Before Socrates, str. 80.

53 Homér, Od. X,191.

54 Homér, Il. VII,422; VIII,485-486.

55 Např. Homér, Il. XVIII,399.

56 Mimnermos, zl. 10 (E. Diehl, Anthologia lyrica graeca, Leipzig 1949, str. 52).

57 Stésichoros, zl. 8,1-4 (J. M. Edmonds, Lyra graeca, II, London - New York 1924, s. 34). 
prostého západu pod viditelný horizont. S výjimkou souhvězdí Medvědic se hvězdy v Ókeanu „koupou“ “ ${ }^{58}$ Znamenalo by to, že jdou pod náš vlastní horizont spojený s pevnou zemí, aniž bylo potřeba vše lépe popsat. Pokud se u Anaximena texty doslova zmiňují o oběhu těles „kolem“ Země, Slunce by mělo procházet právě ókeanickou oblastí. ${ }^{59}$

Problém oběhů nebeských těles nás přivádí k naprosto klíčové skutečnosti. $\mathrm{V}$ představených textech se Země očividně nenalézá volně v prostoru, v němž by byla umístěna a kterým by mohla nebeská tělesa pod ní volně procházet. Celý prostor byl definován a ztělesněn masou Země, kolem níž obtékal Ókeanos a nad níž se klenulo nebe. Vertikální rovina mezi nebem a Zemí pak vyjadřovala vlastní rozsah světa. Universum se pritom rozpínalo pouze $\mathrm{v}$ prostoru mezi plochou Zemí a nebem. V tomto smyslu bychom mohli následně pochopit Xenofana: „Země je bezmezná a není obklopena ani vzduchem, ani nebem. “60

Podobně získává na srozumitelnosti jiný Xenofanův výrok, který lze chápat v tom smyslu, že Země stále ubíhá dolů a sahá tak hluboko, že otázku po jejích mezích ani nelze klást. Pod námi je pouze sama země a zas jen země: ${ }^{61}$ „U nohou je vidět mez Země, dosahující sem nahoru, stýká se zde se vzduchem, zatímco dolní mez ubíhá k bezmeznu."62

Z uvedeného plyne základní předpoklad, z něhož vycházelo iónské archaické kosmologické pojetí - Země není nebeské těleso! Země je masou, která má své útroby. Tvoří základnu celého světa a vymezuje spodní rozsah universa. Je doslova ,podlahou světa“ nad níž se rozprostírá žité universum. Tematizace prostoru pod Zemí tak nedává smysl, nebot' jej vytvárí masa Země. Pokud u Anaximena nalézáme opakované zprávy o oběhu nebeských těles pouze nad Zemí, znamená to, že se pod ní nenalézá žádný volný prostor. Země není někde a v něčem umístěna - naopak vše ostatní z ní vzchází. Podobně pseudo-Plútarchos popisuje jako první pouze vznik Země. Nebeská tělesa pak nutně vznikají až ze Země, přičemž jsou ale pouze jejími výpary.

58 Homér, Il. V,6; XVIII,483-489; Od. V,272-275.

59 Srv. D. R. Dicks, Early Greek Astronomy to Aristotle, Ithaca - New York, str.31-32; G. S. Kirk - J.E. Raven - M. Schofield, Předsókratovštífilosofové, str. 22-25, pozn. 4; E. Luhanová, Zrození světa. Kosmologie básníka Hésioda, Červený Kostelec 2014, str. 205-206, pozn. 119; G. Wöhrle, Anaximenes aus Milet, str. 24.

60 DK 21 A 33.

61 Srv. J. H. Lesher, Xenophanes of Colophon. Fragments, Toronto 1992, str. 129-131.

$62 D K 21$ B 28. 
Pokud jsme výše viděli, že Hippolytos spojuje plochý tvar Země s tím, že je nadnášena vzduchem, je jeho vysvětlení poplatné nové kosmologické koncepci, počítající se Zemí jako nebeským tělesem umístěným v prostoru. Jak jsme rozvedli na jiném místě, tato koncepce podle všech známek začala v italské větvi filosofie - tak jak ji od iónské větve odlišuje Diogenés Laertios -, přičemž později nalezla své vyústění u Aristotela. ${ }^{63}$

\section{Povaha nebeských těles}

Pokud se vrátíme zpět k otázce povahy nebeských těles, můžeme se nyní opřít o důsledky, které z představeného pojetí oběhů nebeských těles plynou.

Musíme si přitom uvědomit, že pokud byla pro celý svět určující rozloha ploché Země, její rozměr musel být oproti nebeským tělesům výrazně větší. Jak upozornil D. L. Couprie, ${ }^{64}$ pokud předpokládáme, že se nad plochou Zemí klene nebe, na němž jsou umístěny hvězdy, největší vzdálenost mezi nebeskými tělesy a povrchem Země by nebyla větší než polovina průměru Země. Samotné Slunce i jednotlivá nebeská tělesa by tak vůči Zemi byla relativně malá. $\mathrm{V}$ arabském prameni máme pro Anaximena i doklad potvrzující, že Slunce považoval za menší než Zemi. ${ }^{65}$ Poměry v universu, jakkoli mohly být pokládány za rozsáhlé, tedy nebyly nesmírné, ale svět byl pokládán za ohraničený. $\mathrm{O}$ tom svědčí již známá Hésiodova pasáž popisující pád kovadliny z nebe na Zemi a následně na dno Tartaru. ${ }^{66}$

Jestliže jsme vymezili rozsah universa pouze mezi plochou Zemí a nebem, přičemž se veškeré dění odehrávalo nad povrchem Země, nad níž se ve vzduchu vznášela nebeská tělesa, je nyní jasné, proč meteorologie měla tak významný vliv v kosmologii. Právě meteorologické pozadí je jedním ze zcela typických momentů spojených s archaickou iónskou kosmologií, v níž se atmosférické a kosmologické jevy výrazně

63 Srv. R. Kočandrle, Hledání původu koncepce rovnovážného umístění Země, in: Aither, 17, 2017, str. 4-31.

64 Srv. D. L. Couprie, Heaven and Earth in Ancient Greek Cosmology from Thales to Heraclides Ponticus, New York 2011, str. 11.

65 Srv. H. Daiber, Aetius Arabus. Die Vorsokratiker in arabischer Überlieferung, Wiesbaden 1980, str. 399.

66 Hésiodos, Theog. 720-725. 
překrývají. D. W. Graham v tomto smyslu hovoří o „meteorologickém modelu“.67

Nebeská tělesa jsou zde téměř vždy spjata se zapálením výparů země a moře. Je to oheň, který tvoří vlastní povahu nebeských těles, a to nejen Slunce a hvězd, ale rovněž Měsíce. Občasné zprávy o osvětlování Měsíce Sluncem lze jednoznačně chápat jako vliv pozdní kosmologie. ${ }^{68}$ Ačkoli Áetios podobně referuje o zemité povaze Slunce a Měsíce u Thaléta, je možné se domnívat, že jde o omyl vycházející z tradice, která Thalétovi přičítala předpověd’ zatmění Slunce. ${ }^{6}{ }^{6}$

Podle Anaximandra byly Slunce a Měsíc tvořeny ohnivými prstenci obklopenými vzduchem charakteru mlhy. ${ }^{70}$ Nebeská tělesa, tak jak je vidíme na obloze, přitom byla pouze průduchem do tohoto mlžného obalu, jímž se odkrýval vnitřní oheň. Nevznikla však až postupně z výparů země a moře, ale jednalo se o přímé pozůstatky po planoucí sfére z prvních fází kosmogonie. ${ }^{71}$ Jak jsme rozvedli na jiném místě, Anaximandros se od ostatních iónských myslitelů navíc odlišuje tím, že nebeská tělesa podle něho procházela pod plochou Zemí. ${ }^{72} \mathrm{~V}$ této souvislosti lze upozornit, že pokud Hippolytos současně zmiňuje protilehlou stranu Země, máme právě u Anaximandra de facto první doklad o Zemi jako o konkrétním nebeském tělese! ${ }^{73}$ Ačkoli tedy Anaximandros navazuje na meteorologický výklad, představuje zároveň myslitele, jehož kosmologické vize nebyly dobově akceptovány. Určující totiž byla kosmologie oběhů nebeských těles nad Zemí a z toho plynoucích důsledků.

Hérakleitos měl připodobňovat nebeská tělesa $\mathrm{k}$ dutým nádobám, podobným míse plné ohně. Jsou k nám otočena dutou částí, přičemž v ní hoří oheň pocházející z výparů země a moře. ${ }^{74}$ Xenofanés zase vymezil nebeská tělesa jako vznícená oblaka nashromážděných částí ohně, pocházejících z výparů vlhkosti. ${ }^{75}$ Povaha nebeských těles - zejména Slunce a Měsíce - je tak analogická. Zpravidla vychází ze zapálených

67 Srv. D. W. Graham, Science Before Socrates, str. 78-84.

68 Např. $D K 12$ A 1; DK 13 A 16.

$69 D K 11$ A $17 \mathrm{a}$.

70 DK 12 A 11; DK 12 A 18; DK 12 A 21; DK 12 A 22.

71 DK 12 A 10.

72 Např. R. Kočandrle, Setrvávání Země v Anaximandrově univerzu, in: Filosofický časopis, 2, 2016, str. 171-188.

73 DK 12 A 11.

74 DK 22 A $1 ; D K 22$ A $11 ; D K 22$ A 12.

75 DK 21 А 32; DK 21 А 33; DK 21 А 38; DK 21 А 40; DK 21 А 43; DK 21 A 44. 
výparů, přičemž je blízká ohni a oblakům. Ačkoli jejich jádrem je oheň, nebot' na nebi svítí, mají zároveň jistou strukturu. U Anaximena bychom proto měli očekávat obdobnou povahu nebeských těles. Musíme přitom rozlišovat mezi povahou tělesa, která je ohnivá, a jeho konkrétní skladbou, která jej utváŕí.

Můžeme přihlédnout k významné roli procesu „plstnatění“ či ,plstění“, který se u Anaximena objevuje na různých místech. ${ }^{76}$ Úzce přitom souvisí s vytvořením kompaktní struktury dané věci. Slunce a Měsíc bychom tak mohli u Anaximena pokládat za tenká a plochá „zplstnatělá“ hořící oblaka vzniklá ze sloučených zapálených výparů země a moře. Vzhledem k jejich oběhům by ovšem byla stálá a nikoli efemérní, jak se dá rozumět zprávám o Slunci Hérakleita a Xenofana. ${ }^{77}$

Ačkoli se P. J. Bicknell pokusil překonat zjevný rozpor mezi zprávami pseudo-Plútarcha a Hippolyta předpokladem zemitého jádra, kolem něhož se „nabaluje“ oheň jinak ohnivých nebeských těles, není vzhledem k charakteru Anaximenovy kosmologie k podobné domněnce důvod. ${ }^{78}$

Pokud se ohnivá povaha nebeských těles zakládá na vlhkosti světa, pak aby mohla hořet, musí se za touto vlhkostí pohybovat. ${ }^{79}$ I obraty Slunce a Měsíce byly analogicky vyloženy tak, že k nim dochází působením vzduchu: „O obratech Slunce. Anaximenés [říká], že hvězdy ( $\tau \grave{\alpha}$

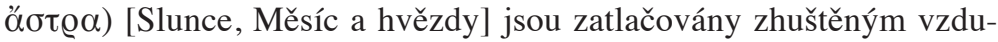
chem, který jim klade odpor." ${ }^{\text {"80 }}$

Áetiův text se týká obratů Slunce a pojednává o jeho pravidelných severo-jižních pohybech. V textech však bohužel není přiblížen každodenní pohyb Slunce od východu k západu. Ačkoli badatelé občas v archaické iónské kosmologii usuzují na působení víru, lze se domnívat, že původcem kosmologické role víru byl až Anaxagorás. ${ }^{81}$ Dá se předpokládat, že vlastní kinematika universa - a tedy i pohyb

76 DK 13 A 6; DK 13 A 7. Proces plstění přibližuje zejména R. Hahn, Heraclitus, Milesian Monism, and the Felting of Wool, in: E. Fantino - U. Muss - Ch. Schubert - K. Sier (vyd.), Heraklit im Kontext, Berlin - Boston 2017, str. 193-202.

77 DK 21 A 33; DK 21 A 41; DK 22 B 6.

78 Srv. P. J. Bicknell, Anaximenes’ Astronomy, str. 56-57, 69-74.

79 DK 12 A 27.

$80 \quad D K 13$ A 15.

81 Srv. D. W. Graham, Science Before Socrates, str. 127, pozn. 24; A. Gregory, Ancient Greek Cosmogony, London 2007, str. 116; W. A. Heidel, The dív $\eta$ in Anaximenes and Anaximander, in: Classical Philology, 1, 1906, str. 279-282. 
Slunce od východu k západu - obecně souvisela s vlivem vzduchu, větru a interakcí mezi vlhkostí na zemském povrchu a teplem Slunce.

Výrazná role vzduchu se uplatňuje i ve vysvětlení měsíčních fází nebo zatmění Slunce. Ačkoli Áetios vypisuje názory různých myslitelů objasňující zatmění Slunce, Anaximenovo jméno vynechává. Pokud však Milét'an ztělesňoval typické myšlení své doby, mohli bychom mu připsat anonymní koncepci, kterou zde Áetios uvádí: ${ }^{22}$ „O zatmění Slunce. Někteří tvrdí, že [zatmění Slunce] je zahuštěnina oblaků, které se nepozorovaně nakupí před sluneční disk." ${ }^{\text {"83 }}$

Meteorologická podstata vysvětlení nebeských těles přítomná v archaické iónské kosmologii vyvstane zejména v porovnání s tzv. „lithickým modelem“, který představil D. W. Graham. Tento model, jehož počátek je spojen s Anaxagorou, jednoznačně ukazuje odlišnost kosmologií z doby po Parmenidovi ${ }^{84}$ Zde jsou nebeská tělesa naopak vykládána jako konkrétní hmotné objekty. Když se již universum nenalézalo pouze mezi nebem a Zemí, ale Země v něm byla umístěna jako jedno z těles, přičemž oběh ostatních nebeských těles pod ni volně zasahoval, výpovědní hodnota meteorologického modelu vzala za své.

Akceptujeme-li tento základní přeryv v kosmologickém výkladu a uplatníme-li jej zpětně na Anaximena, zemité přirozenosti či zemitá tělesa, která nejsou viditelná, s nimiž se u něho setkáváme, budou pouze přídavkem pozdní kosmologie. Jejich koncepce byla Anaximenovi pravděpodobně přiřknuta $\mathrm{v}$ důsledku analogií jeho myšlení s Anaxagorou, u něhož máme doklady o tom, že o těchto tělesech hovořil..$^{85}$

\section{Hvězdy a nebe}

Výše uvedený popis se vztahuje především na Slunce a Měsíc. Výklad hvězd ovšem navíc souvisí s předpokladem nebeské klenby, která by shora uzavírala universum, podobně jako je zdola definuje rozsah Země. Dojem nebeské klenby téměř sugeruje zkušenost, kdy hvězdy během zdánlivého pohybu nebe udržují vůči sobě stálé pozice.

Z generálního užití termínu ǒođ@ $\alpha$, který v textech zastupuje nejen hvězdy, ale nebeská tělesa obecně, lze soudit, že vznik a povaha hvězd

82 Srv. D. W. Graham, Science Before Socrates, str. 64.

83 Z1. 25, in: D. W. Graham, The Texts of Early Greek Philosophy, str. 82-83.

84 Srv. D. W. Graham, Science Before Socrates, str. 135.

85 DK 59 A 42. 
jsou analogické vzniku Slunce a Měsíce. Hvězdy tak podobně vznikají z výparů vlhkosti, přičemž jsou ohnivé.

Jinak to však může být s jejich tvarem a umístěním. Přisuzuje-li Hippolytos ${ }^{86}$ plochý tvar nejen Zemi, Slunci a Měsíci, ale rovněž „všem ostatním hvězdám“, které se díky němu „,vznášejí ve vzduchu“, Áetios umožňuje i jiné pochopení: „O tvarech hvězd: Anaximenés [ř́íkal, že hvězdy] jsou připevněny v křišt'álovém [nebi] jako hřebíky. Někteří je však mají za ohnivé lístky, jako obrázky.“87

Ačkoli dané znění uvádí edice Hermanna Dielse a Walthera Kranze, je doloženo pouze ve verzi Áetia u pseudo-Plútarcha ${ }^{88}$ Stobaios ${ }^{89}$ Eusebios ${ }^{90}$ nebo pseudo-Galénos ${ }^{91}$ zachovávají jen první větu. Věta ,někteří je však mají za ohnivé lístky“ je někdy pokládána za vsuvku týkající se ostatních nebeských těles, přičemž termín „obrázky“ by se vztahoval k hvězdám upevněných na nebeské klenbě. Text by tak kombinoval informace týkající se fixovaných hvězd a zároveň ostatních volně se pohybujících nebeských těles. O znalosti planet ale nemáme v archaické iónské kosmologii žádné zaručené doklady. ${ }^{92}$

Badatelé, kteří argumentovali ve prospěch původnosti pasáže, předložili celou řadu možných interpretací. Například P. J. Bicknell navrhl chápat „křišt'álové“ nebe v souvislosti s protisvitem, slabou září, která je na noční obloze pozorovatelná na straně opačné vůči Slunci. William K. C. Guthrie naopak zaměřil pozornost na oblast fyziologie, konkrétně

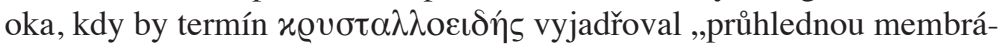
nu“ oční čočky. ${ }^{93}$

\footnotetext{
$86 D K 13$ A 7.

87 DK 13 A 14.

88 Srv. H. Diels, Doxographi Graeci, Berlin 1879, str. 344.

89 TP 2 As 124.

90 TP 2 As 89.

91 TP 2 As 180.

92 Srv. P. J. Bicknell, Anaximenes' Astronomy, str. 53-56; D. W. Graham, Science Before Socrates, str. 2013, str. 64, pozn. 78; The Texts of Early Greek Philosophy. The Complete Fragments and Selected Testimonies of the Major Presocratics, I, Cambridge 2010, str. 82-83; T. Heath, Aristarchus of Samos. The Ancient Copernicus, Oxford 1913, str. 42; U. Hölscher, Anaximander und die Anfänge der Philosophie, str. 413-414; H. Schwabl, Anaximenes und die Gestirne, in: Wiener Studien, 79, 1966, str. 33-38; M. L. West, Early Greek Philosophy and the Orient, str. 102; G. Wöhrle, Anaximenes aus Milet, str. 27, 72.
}

93 Srv. P. J. Bicknell, Anaximenes' Astronomy, str. 74-75; Anaximenes and the Gegenschein, in: Apeiron, 11, 1977, str. 49-52; W. K. C. Guthrie, Anaximenes and 
Jak se v dané souvislosti ovšem upozorňuje, koncepce hvězd umístěných na „křrišt'álu nebe“ odpovídá Empedokleovi, který je měl v tomto smyslu odlišovat od volných planet.$^{94}$ Navíc stejný termín u něho Áetios opakovaně používá při popisu nebe či Slunce, ${ }^{95}$ přičemž tak činí i další

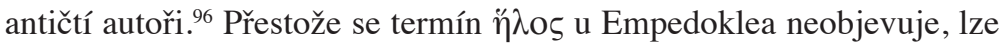
vyslovit domněnku, že se Áetiův text ve skutečnosti týká právě jeho. ${ }^{97}$

Čteme-li Áetiovu pasáž vytrženou z kontextu kapitoly o tvaru hvězd, vyvstává dojem, že termín ěvıo může zastupovat myslitele, kteří, oproti koncepci pevně umístěných hvězd, připisovali Anaximenovi hvězdy v podobě ohnivých lístků. Pokud však přihlédneme k textu celé (stručné) kapitoly, shledáme, že se v ní nejedná o postupné přiřazení toho kterého tvaru hvězd jednotlivým myslitelům, nýbrž o ukázání různých tvarů, které byly předpokládány. Konkrétně se objevují: sféra, kužel, hřeb a plochý lístek. Jmenovitě jsou přitom uváděni stoici, Kleanthés a Anaximenés. Zatímco podle stoiků měly být hvězdy kulovité, Kleanthés se měl domnívat, že byly kuželovitého tvaru. Edice Jaapa Mansfelda a Davida T. Runiy následně odlišuje další dvě pozice ve smyslu tvaru hvězd umístěných na vnější sférée. Zatímco v případě Anaximena se mělo jednat o trojdimenzionální hřeby, jako dvoudimenzionální ohnivé lístky si je měli naproti tomu představovat právě „,někteří myslitelé“ ("̌viol), kteří nejsou uvedeni jmenovitě..$^{9}$

Pokud byl Anaximenés opravdu uveden omylem namísto Empedoklea, zmínka o ohnivých lístcích, jakkoli se objevuje jen u pseudoPlútarcha, může indikovat původ záměny jmen. Anaximena bychom tak mohli zahrnout do této anonymní skupiny „některých“ myslitelů, která si hvězdy takto vizualizovala. Představoval by přitom jejího typického zástupce, jak lze usoudit na základě doloženého analogického tvaru Slunce a zároveň Hippolytova svědectví o plochých hvězdách.

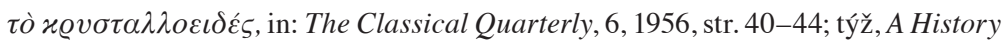
of Greek Philosophy, I, The Earlier Presocratics and the Pythagoreans, Cambridge 1962, str. 136-137.

$94 D K 31$ A 54.

95 DK 31 A 51; DK 31 A 56.

96 DK 31 A 1; DK 31 A 51. Lactantius (DK 31 A 51) obdobně hovoří o nebi jako o ,zmrzlém vzduchu“.

97 Srv. G. S. Kirk - J. E. Raven - M. Schofield, Předsókratovští filosofové, str. 200; J. Longrigg, KPY $\Sigma T A \Lambda \Lambda O E I \Delta \Omega \Sigma$, in: The Classical Quarterly, 15, 1965 , str. 249-251.

98 Srv. J. Mansfeld - D. T. Runia, Aëtiana. The Method and Intellectual Context of a Doxographer, II, The Compendium, 2, Leiden - Boston 2009, str. 474-475. 
Hvězdy by tak podle Anaximena vznikaly zapálením výparů stoupajících z moře a země, které se ve výši shlukly do tvarů „ohnivých lístkư“. Ačkoli nemáme jednoznačný text popisující pořadí nebeských těles, lze se domnívat, že se hvězdy nalézaly nejdále od Země, zatímco pod nimi se pohybovaly Slunce a Měsíc. Tak můžeme rozumět Hippolytovu postřehu, že „hvězdy nehřejí proto, že jsou velice daleko.“99

Jestliže se hvězdy nalézaly nejvýše z nebeských těles a Áetios záro-

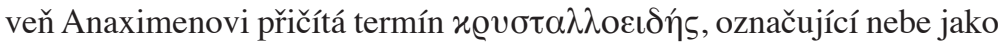
„křišt’álové“, vtírá se do Anaximenovy kosmologie představa nebeské klenby, tedy koncept, který u jeho předchůdce Anaximandra doložen není. Předpoklad klenby však není jednoznačný. Kromě uvedeného Áetiova textu by mu mohl ještě nahrávat motiv plstěného klobouku a rovněž další Áetiova zmínka: „O nebi, jaká je jeho jsoucnost: Anaximenés tvrdí, že nejzazší okruh je zemitý. “100

Je třeba rozlišovat mezi nebem a nebeskou klenbou, která by je ohraničovala, a tím by vymezovala i celý svět. Obvyklé výklady kosmologií předsókratiků přitom běžně pracují s pevnou nebeskou klenbou ve tvaru hemisféry. ${ }^{101} \mathrm{~K}$ tomuto zdánlivě evidentnímu předpokladu však není v textové bázi de facto opora. Podobně již ve výkladu Homéra např́íklad Geoffrey S. Kirk tvrdí: „nebe je polokoule z pevného materiálu podobná číši“", ${ }^{102}$ ačkoli Homér se na klíčových místech vyjadřuje pouze o „bronzovém“"103 nebo ,železném“ nebi. ${ }^{104}$ Přestože by tak mohla být $\mathrm{v}$ souvislosti s kovem vyjádřena nejen zářivost, ale i pevnost nebe, potvrzení vlastní existence klenby není bez problémů. Když ale podle Hésioda zrodila Země jako prvního z potomků Nebe, mělo jí být „,podobné“ a „halit kolem dokola“. ${ }^{105} \mathrm{~V}$ dalších fázích byl Úranos od Země oddělen a následně nad ní držen Atlantem. ${ }^{106}$ Motiv oddělení Země a Nebe je navíc přítomný v různých kulturách, kde Nebe představuje jednu z konkrétních kosmogonických stran. Ačkoli texty přinášejí

$99 D K 13$ A 7.

$100 D K 13$ A 13.

101 Srv. D. L. Couprie, The Paths of the Celestial Bodies According to Anaximenes, str. 10.

102 Srv. G. S. Kirk - J. E. Raven - M. Schofield, Předsókratovští filosofové, str. 20.

103 Homér, Il. V,504; XVII,425; Od. III,2.

104 Homér, Od.XV,329; XVII,565.

105 Hésiodos, Theog. 126-128.

106 Tamt., 517-520; 746-748. 
o nebeské klenbě jen různé náznaky, lze přesto z podobných indicií usoudit, že nebe bylo „něčím“. Pokud Země představovala spodní vymezení světa, nebeská klenba vyjadřovala horní hranici. ${ }^{107}$

Vzhledem k výše uvedenému popisu Země, pod níž se nenalézal žádný prostor, je ovšem možné soudit, že nebe nepředstavovalo celou sféru, jak navrhují P. J. Bicknell nebo D. L. Couprie, ale mohlo být vyjádřeno spíše hemisférou - polokoulí, která zakrývá povrch Země. ${ }^{108}$ $\mathrm{K}$ ní poukazuje motiv plstěného klobouku, kterým mohla být míněna čapka zhotovovaná z plstě či vlny, případně klobouk se širokou střechou, jakým byl petasos. Zároveň je ovšem možné uvažovat o tom, že se jednalo o jinou pokrývku hlavy, např́klad sestávající ze stočené látky, či o turban. Navíc jsme v čínské koncepci gai tian viděli, že nebe může představovat i plochou rovinu. U Anaximena by plochý tvar podporovalo pojetí nebeských těles. Ačkoli celá koncepce nemusela být dostatečně vizualizována, lze se na základě motivu plstěného klobouku domnívat, že bychom měli zakřivení nebe předpokládat. ${ }^{109}$

Viděli jsme, že hvězdy měly vznikat ze zapálených výparů, přičemž představa lístků odpovídá meteorologickému pozadí celé koncepce. Na rozdíl od Slunce a Měsíce však během svého pohybu udržují navzájem stálé pozice. Pokud hvězdy vznikají jako výpary, mohly být následně uchyceny na parném - plsti podobném - nebi, na místech u nebeské klenby, kde se shlukl jejich oheň. Mohlo by se tak obecně jednat o hvězdy líčené co do své povahy a tvaru jako ohnivé lístky situované v přirozeném vzdušném prostředí, současně se přitom nalézající u „nejzazšího nebeského okruhu“, unášené jeho pohybem a fixované tak vůči sobě navzájem. Zmínka o „otáčení plstěného klobouku“ by přitom tlumočila pohyb celého nebe. Zásadní je právě odlišení pohybu hvězd od Slunce a Měsíce. Východy a západy hvězd by ovšem byly podobně iluzorní, jako je tomu v prŕípadě Slunce.

107 Srv. F. M. Cornford, Principium Sapientiae. The Origins of Greek Philosophical Thought, New York 1965, str. 194-195; G. S. Kirk - J. E. Raven - M. Schofield, Předsókratovští filosofové, str. 20, 53-63.

108 Srv. P. J. Bicknell, Anaximenes' Astronomy, str. 77; D. L. Couprie, The Paths of the Celestial Bodies According to Anaximenes, str. 29-30.

109 Srv. P. J. Bicknell, Anaximenes' Pilion Simile, in: Apeiron, 1, 1966, str. 17-18; G. E. R. Lloyd, Polarity and Analogy. Two Types of Argumentation in Early Greek Thought, Cambridge 1966, str. 318-319. 


\section{Závěrem}

Pokud shrneme obraz Anaximenovy kosmologie, lze říci, že se nejedná o krok zpět od Anaximandrova pojetí, jak se běžně uvádí. Anaximenova koncepce naopak podle všech známek představuje hlavní proud archaického iónského vysvětlení poměrů světa, který se odvíjel od epické tradice a který lze dokladovat ještě u Xenofana. Není proto překvapením, že právě o Anaximenovi měl Theofrastos napsat spis. U Anaximena můžeme nalézt typické znaky většiny archaických iónských kosmologických koncepcí, založených na předpokladu universa prostírajícího se mezi plochou Zemí a nebem, kde nebeská tělesa byla pokládána za meteorologické jevy. Měla vznikat v důsledku vypařování vlhkosti Země a jejich pohyb byl spoluurčován působením vzduchu. Tento obraz universa se zásadně změnil s př́íchodem nových koncepcí počítajících s umístěním Země v prostoru, v němž se nebeská tělesa stávala konkrétními hmotnými objekty. ${ }^{110}$

\section{ZUSAMMENFASSUNG}

Die Kosmologie des Anaximenes von Milet wird gegenüber den Visionen seines Vorgängers Anaximandros oft als Rückschritt betrachtet. Manches darin bleibt unklar, z.B. der Charakter der Gestirne und deren Bewegung um die Erde. Falls Anaximenes jedoch, wie im vorliegenden Artikel gezeigt wird, das Weltganze nur zwischen der flachen Erde und dem Himmel dachte, lie $\beta$ er die Gestirne durch Entflammen von Erdausdünstungen entstehen und Bahnen nur über die Erdoberfläche verlaufen. Sonnenaufgang und Sonnenuntergang waren ihm dann eine durch das Sich-Entfernen der Sonne vom Betrachter entstehende optische Täuschung. Da derartige Ansätze noch bei Xenophanes zu finden sind, kann Anaximenes' Konzept als für seine Zeit maßgeblich gelten.

SUMMARY

The cosmology of Anaximenes of Miletus is often seen as a step back from the visions of Anaximander, his predecessor. Various parts of it, meanwhile, are still unclear, including for instance the nature of heavenly

110 Studie je součástí grantového projektu GA ČR GA15-08890S. 
bodies or their path around the Earth. If, as it seems, Anaximenes assumed the universe stretches only between a flat Earth and the heaven, heavenly bodies arose by ignition of vapours rising from the Earth and moved only above its surface. Sunrise and sunset were merely an optical illusion given by the Sun's movement away from the observer. Given that similar ideas are found also in the writings of Xenophanes, one might assume that Anaximenes' conception was typical of this period. 